\title{
Review
}

\section{The Sex Determination Cascade in the Silkworm}

\author{
Xu Yang ${ }^{1,2}$, Kai Chen ${ }^{1,2}$, Yaohui Wang ${ }^{1}$, Dehong Yang ${ }^{1,2}$ and Yongping Huang ${ }^{1, *}$ \\ 1 Key Laboratory of Insect Developmental and Evolutionary Biology, Center for Excellence in Molecular Plant \\ Sciences, Shanghai Institute of Plant Physiology and Ecology, Chinese Academy of Sciences, \\ Shanghai 200032, China; yangxu@cemps.ac.cn (X.Y.); chenkai2015@cemps.ac.cn (K.C.); \\ yhwang@cemps.ac.cn (Y.W.); yangdehong@cemps.ac.cn (D.Y.) \\ 2 University of Chinese Academy of Sciences, Beijing 100049, China \\ * Correspondence: yphuang@sibs.ac.cn
}

Citation: Yang, X.; Chen, K.; Wang, Y.; Yang, D.; Huang, Y. The Sex Determination Cascade in the Silkworm. Genes 2021, 12, 315. https://doi.org/10.3390/genes12020315

Academic Editor: Artyom Kopp and Giuseppe Saccone

Received: 17 November 2020

Accepted: 9 February 2021

Published: 23 February 2021

Publisher's Note: MDPI stays neutral with regard to jurisdictional claims in published maps and institutional affiliations.

Copyright: () 2021 by the authors. Licensee MDPI, Basel, Switzerland. This article is an open access article distributed under the terms and conditions of the Creative Commons Attribution (CC BY) license (https:// creativecommons.org/licenses/by/ $4.0 /)$.

\begin{abstract}
In insects, sex determination pathways involve three levels of master regulators: primary signals, which determine the sex; executors, which control sex-specific differentiation of tissues and organs; and transducers, which link the primary signals to the executors. The primary signals differ widely among insect species. In Diptera alone, several unrelated primary sex determiners have been identified. However, the doublesex $(d s x)$ gene is highly conserved as the executor component across multiple insect orders. The transducer level shows an intermediate level of conservation. In many, but not all examined insects, a key transducer role is performed by transformer (tra), which controls sex-specific splicing of $d s x$. In Lepidoptera, studies of sex determination have focused on the lepidopteran model species Bombyx mori (the silkworm). In B. mori, the primary signal of sex determination cascade starts from Fem, a female-specific PIWI-interacting RNA, and its targeting gene Masc, which is apparently specific to and conserved among Lepidoptera. Tra has not been found in Lepidoptera. Instead, the B. mori PSI protein binds directly to $d s x$ pre-mRNA and regulates its alternative splicing to produce male- and female-specific transcripts. Despite this basic understanding of the molecular mechanisms underlying sex determination, the links among the primary signals, transducers and executors remain largely unknown in Lepidoptera. In this review, we focus on the latest findings regarding the functions and working mechanisms of genes involved in feminization and masculinization in Lepidoptera and discuss directions for future research of sex determination in the silkworm.
\end{abstract}

Keywords: sex determination; cascade; Lepidoptera insects; silkworm

\section{Introduction}

Sexual reproduction is an evolutionarily ancient feature. Recombination of chromosomes from two parents can result in the emergence or the loss of genes during meiosis. Sexes are the prerequisite for sexual reproduction, and sex determination systems are diverse [1]. Different types of sex chromosomes and various sex-determining genes have developed over the course of evolution. In insects, different compositions of sex chromosomes, such as $\mathrm{XY}, \mathrm{X} 0, \mathrm{WZ}$ and $\mathrm{Z} 0$, are observed, and the signaling pathways involved in sex determination are poorly conserved [2-4]. In the model organism Drosophila melanogaster, the primary signal of sex determination is composed by X-linked signal elements (XSE) and regulates the transcripts of Sex-lethal $(S x l)$, the transducer is encoded by transformer (tra) and transformer 2 (tra2), and the executors are encoded by doublesex (dsx) and fruitless (fru) [5-7]. Studies of Drosophila and other insects, such as Apis mellifera, Nasonia vitripennis and Tribolium castaneum, have established that the primary signals coming from the sex chromosomes are diverse among species; whereas the transducers and executors, encoded by genes located on autosomes, are more highly conserved [8-13]. The novel sex determination factors that function as primary signals have been identified in Diptera in recent years. They include Nix, which is a distant homolog of tra2 and which was identified in Aedes 
aegypti; YoB, which is a maleness gene in Anopheles gambiae; $M d m d$, a splicing factor that was identified in Musca domestica; and MoY, the Y-linked, male-determining factor in the Ceratitis capitata, which is also functionally conserved in Bactrocera dorsalis, Bactrocera oleae and many other Teprhtidae species [14-18]. Although these factors are diverse, the primary signal mediated by these genes is transduced by a pathway that leads to alternative splicing of $d s x$, which controls sex differentiation eventually [19]. However, due to the absence of tra in mosquitos and because $S x l$ orthologs are not involved in primary sex determination in Medfly and Musca species, only the terminal genes within the sex determination pathway are conserved in Diptera [20].

Lepidoptera is a diverse order of insects that includes both pests and species of economic importance such as pollinators and silk producers [21]. The mechanism of sex determination in lepidopterans is quite different from that in dipterans [22]. The lepidopteran model species Bombyx mori uses a WZ/ZZ sex determination system, in which homozygous ZZ makes males, whereas heterozygous WZ makes females. This implies that the sex determiner is a female factor (F-factor) from the $\mathrm{W}$ chromosome [23]. Studies using high-throughput sequencing and genome editing technologies have identified unique sex determination genes in lepidopterans such as Silkworm-PIWI (Siwi), gametocyte-specific factor 1 (Gtsf1), Masculinizer (Masc) and P-element somatic inhibitor (PSI), and have preliminarily established the molecular mechanism of the sex determination cascade in Lepidoptera [21,24-28] (Figure 1). Here we summarize the progresses of sex determination studies achieved in recent years in lepidopteran and compare them with the model $D$. melanogaster. We also suggest further directions in the Lepidoptera model B. mori that will provide insights into sex determination in other Lepidoptera species.

\section{Overview of the Sex Determination Cascade in the Silkworm}

The sex determination pathways in insects are diverse [2]. The diversity arises mostly from primary signals, whereas transducers and executors are more conserved [29,30]. In D. melanogaster, $M$. domestica and C. capitata the primary sex determiner controls sex development via Tra-transduced signaling pathway, resulting in the alternative splicing of $d s x[5,16,17]$. The transducer gene usually encodes a splicing factor, and manipulation by the primary signals therefore exists or functions as a sex determiner only in one sex. The products of the executor gene $d s x$ act downstream of these switches. There are female- and male-specific isoforms of DSX, which control sexual development in most insect species [31]. However, in the silkworm, the ortholog of tra does not exist, and no $d s x$ cis-regulatory element binding sites are found, which indicates the sex determination pathways are markedly different from those seen in flies [20,32].

In the lepidopteran model species B. mori, the primary signal is the PIWI-interacting RNA (piRNA) Fem, which is derived from the W chromosome [24]. Fem silences a gene unique to Lepidoptera, Masc, which is essential for both male determination and repression of the vital process of dosage compensation of Z-linked genes during embryogenesis (Figure 1) [21,26,33-35]. In recent years, sex-determined factors encoded by PSI, Znf-2, Siwi and Gtsf1 have been identified along with preliminary established genetic cascade of the sex determination in the silkworm $[25,27,28,33,36]$. 

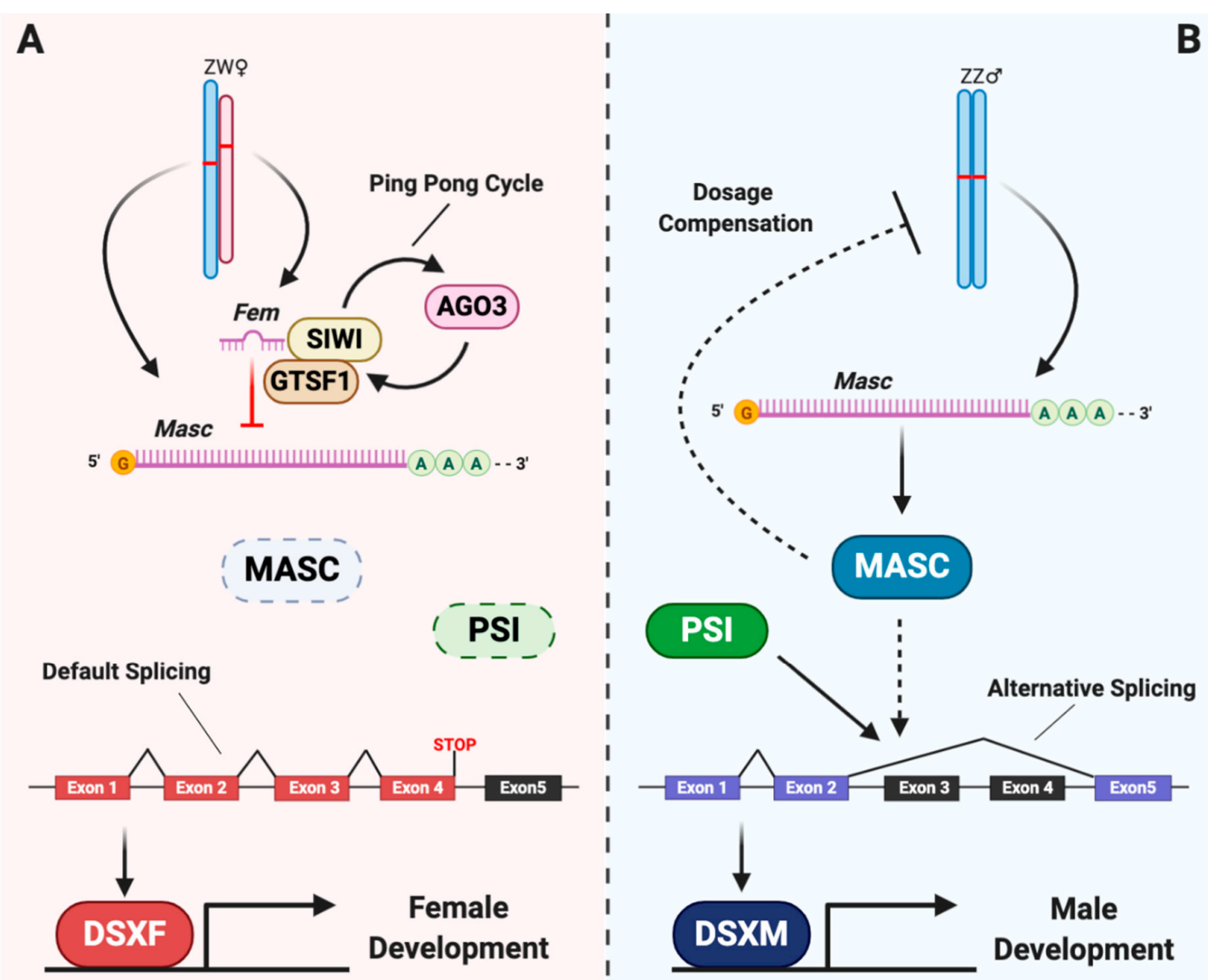

Figure 1. The preliminary established genetic cascade of sex determination in Bombyx mori. Female development is the default sex determination pathway in B. mori (A). The Feminizer piRNA (Fem) derived from the female W chromosome interacts with the proteins Silkworm-PIWI (SIWI) and gametocyte-specific factor 1 (GTSF1) to form as piRNA-induced silencing complexes and silence Masculinizer (Masc) at the mRNA level during ping-pong amplification with Argonaute RISC Catalytic Component 3 (AGO3) [24,25]. The absence of Masc protein (MASC) and an inactive P-element Somatic Inhibitor protein (PSI) results in production of the female-specific isoform of $d s x(d s x F)$, which contain all of the exons of the gene [33]. The female-specific DSX (DSXF) results in female morphological sex characteristics $[37,38]$. MASC is expressed normally in the male due to the lack of Fem and presence of active PSI (B), and this results in dosage compensation and splicing that produces the male-specific isoform of $d s x(d s x M)$, which contains exons of 1,2 , and 5 of the $d s x$ pre-mRNA [33,36]. The male-specific DSX (DSXM) promotes male development $[37,38]$.

\section{Feminizers, the Primary Signals}

Research on sex determination factors in the silkworm began in 1933 when Hasimoto hypothesized that the F-factor originates from the W chromosome [39]. Subsequent genetic studies showed that one copy of the $\mathrm{W}$ chromosome is sufficient to determine femaleness [40]. However, in part due to the various transposable elements, their remnants, and simple repeats on $\mathrm{W}$ chromosome, the identity of the F-factor was a mystery [41,42]. Only recently was the F-factor identified when researchers used new generation sequencing technologies, bioinformatics and focused on non-coding RNAs (such as microRNAs, long non-coding RNAs and piRNAs). The F-factor is a single piRNA derived from a piRNA precursor named Fem, which is transcribed from the $\mathrm{W}$ chromosome. Fem functions as the primary determinant of female sex in the silkworm [24,43-47].

piRNAs are a class of small RNAs of 24-31 nucleotides in size. They are produced from transposons and from discrete genomic loci called piRNA clusters. The piRNAs guide PIWI proteins to target transcripts [48,49]. In flies, piRNAs and PIWI proteins mainly function in germ cells during gametogenesis to suppress transposable elements, which are selfish genomic elements that are able to jump around the genome [48,49]. It is fascinating 
that the Fem-derived piRNA participates in sex determination, which is a somatic cell fate event in the silkworm. The piRNA pathway is not well characterized in vivo, and as a result how Fem functions at the molecular level is still a puzzle [50]. piRNAs have no enzyme activity, and instead they assemble into piRNA-induced silencing complexes (piRISCs) with the PIWI proteins such as Siwi and Argonaute RISC Catalytic Component 3 (Ago3) identified in the silkworm [43]. After loading onto PIWI proteins, piRNAs are produced by a unique biogenesis pathway called the "ping-pong" cycle. The ping-pong cycle is a posttranscriptional gene-silencing mechanism in which RNAs degraded by piRNAguided transcript silencing provide substrates for additional piRNA production [51]. We have discovered that SIWI is crucial for feminizing the silkworm, whereas Ago3 mutants display no phenotype involved in sex determination [25]. Our studies suggest that SIWI is dominant during Masc mRNA silencing via Fem-piRNA, whereas Ago3 have minor effects on Fem piRNA processing.

The demonstration that piRNAs have a function in sex determination in the silkworm prompted us try to understand the intricate biogenesis of PIWI-interacting RNAs. The sex determination cascades, as well as piRNA pathways, are distinct in D. melanogaster and B. mori [50]. The piRNA biogenesis pathway consists of a list of components which are specialized for their processing [52]. However, several key elements of the piRNA pathway in the fly, such as $\mathrm{Yb}$, Rhino, Deadlock and Cutoff, which are crucial for piRNA transcription initiation and piRNA processing, are absent in the silkworm [52]. We have reported that a conserved component of the piRNA pathway called Gtsf1 is involved in female sex determination in the silkworm [28]. In Drosophila, Gtsf1 is required for female fertility and interacts with PIWI via its C-terminal end; and it is also essential for piRISCsinduced transposon silencing but not for piRNA biogenesis [53,54]. In the silkworm Gtsf1 is not only necessary for transposon silencing but also for piRNA biogenesis [28]. In addition, our co-immunoprecipitation experiments suggested that Gtsf1 interacts with SIWI. Such an interaction was also observed in Drosophila $[28,53,54]$. Interestingly, not every component from the piRNA pathway participates in feminization. For instance, Maelstrom (Mael) is essential for spermatogenesis and oocyte development in Drosophila as it is involved in piRNA-mediated silencing of transposable elements [55]. However, depletion of Mael in the silkworm leads to spermatogenesis defects but does not affect sexual development [56]. The poly $(A)$-specific ribonuclease-like domain-containing (Pnldc1) is necessary for piRNA maturation in silkworms, and mutation of Pnldc1 leads to abnormalities in nuclei of cells in eupyrene sperm bundles but not cells of other organs $[57,58]$. We have generated transgenic lines using CRISPR-Cas9 technology with mutations in Zucchini and Papi, which encode enzymes required for 3'-end processing of piRNAs, in Tdrd12 and Tudor-SN, which are involved in ping-pong cycling, and in Yu, Armi and Mino, which encode chaperonins that function during piRNAs biogenesis, but none of these lines exhibit any obvious phenotypes (unpublished data). However, all these genes are crucial for piRNA processing in Drosophila, and their mutation will cause sterility, whereas our results indicate that the piRNA processing pathway is also different between silkworms and flies, and the processing of the primary signal Fem-piRNA is independent of those elements [52]. Furthermore, we do not understand how Fem transcription is activated, and it is possible that piRNAs other than Fem or non-coding RNAs from $\mathrm{W}$ are involved in sex determination. If other non-coding RNAs from $\mathrm{W}$ are involved in the female sex determination of B. mori, their role is expected to be minor if compared with Fem. Indeed, Fem repression is sufficient to cause masculinization of $d s x$ splicing in embryos.

\section{Masculinizers, the Possible Transducers}

Masc is the target gene of the primary signal mediated by Fem [24]. Evolutionary analysis revealed that Masc is conserved among the species in Lepidoptera but is not found in other insects, indicating that the sex determination pathway in Lepidoptera is likely distinct [18]. In the silkworm, Masc is located on the $Z$ chromosome [24]. It encodes a $\mathrm{CCCH}$-tandem zinc-finger protein and controls both masculinization and dosage 
compensation [59]. Recent studies have demonstrated that Masc is also required for masculinization in multiple lepidopterans including Trilocha varians, Ostrinia furnacalis and Agrotis ipsilon [21,34,35]. Besides, it is interesting that in O. furnacalis, Wolbachia-induced male-specific lethality is also caused by a failure of dosage compensation via suppression of Masc [60]. However, it remains to be determined whether Masc functions as masculinizer among all the species in the Lepidoptera order. A novel splice variant of Masc (Masc-S), which lacks the intact sequence of the cleavage site for Fem-piRNA, encodes a C-terminal truncated protein that has been identified in both sexes. The variant of Masc, Masc-S, participates in female genital development in the silkworm [61]. Moreover, there is still a gap between Masc and $d s x$, and further investigations that identify the direct targets of Masc will be able to clarify its role.

In Drosophila females, female-specific $d s x$ is promoted by Tra and Tra- 2 as trans-acting splicing activators [5,29] (Figure 2E). In Bombyx, lacking tra ortholog, the sex-specific splicing regulation of the $d s x$ gene is different (Figure 2F). A splicing factor might have replaced the function as Tra in transformer-less species during evolution $[9,62,63]$. PSI is a $\mathrm{KH}$-domain RNA-binding splicing factor that regulates tissue-specific alternative splicing of P-element transposon transcripts to restrict transposition activity to germ-line tissues and that influences development and mating behavior in flies [64-69]. Though PSI is not involved in the sex determination pathway in Drosophila, it is a key auxiliary factor in silkworm male sex determination. PSI binds to exon 4 of $d s x$ pre-mRNA and facilitates its male-specific splicing [36]. Genetic evidence, by using a transgenic CRISPR/Cas9 system, has shown that the mutation of PSI will cause partial male-to-female defects, whereas it has been demonstrated that it is indispensable for masculinization in the silkworm [33]. It is still unclear that PSI affects only males, however, as it is present in both sexes. Besides, according to published reference genomes, PSI is present in multiple lepidopterans, but whether it is involved in sex determination still remains to be identified [70]. Recently, it was reported that a Znf-2 mutant has a phenotype similar to that of the PSI loss-of-function mutant [27]. Znf-2 encodes a CCCH-type zinc finger protein and contributes to malespecific splicing of $d s x$ in silkworm cell lines [71]. The Znf-2 mutant males have feminized external genitalia, and the female isoform of $d s x$ is detected in males, indicating that Znf-2 is essential for male sexual differentiation [27]. In addition, larval development is delayed and body size diminished in PSI and Znf-2 mutant males, demonstrating that these factors have functions in development in the silkworm.

There is strong evidence supporting that Masc, PSI and Znf-2 are indispensable for masculinization, but where and how exactly these factors function in the sex determination cascade is not known. These questions may be answered by dissection of the functional relationships among Masc, PSI and Znf-2, and by identification of additional players in the sex determination pathway. Recent studies have identified components as BxRBP1, BxRBP2 and BxRBP3 (Bombyx mori $d s x$ RNA-binding proteins) are $d s x$ pre-mRNA binding protein by using the strategy of yeast three-hybrid screening. It is interesting that the alternatively transcribed $B x R B P 3$ isoforms are regulated by Masc and physically interact with PSI, but whether $B \times R B P 3$ is the transducer remains to be verified via genetic methods [72] (Figure $2 \mathrm{D}, \mathrm{F})$. However, based on the observation that females can be completely reversed to males when the signal transducer tra is knocked-down or knocked-out in Diptera, we speculate that the transducer in the silkworm either has not yet been identified or may act very differently in the sex determination cascade [19,73-76].

\section{Doublesex, the Executor}

DSX protein sex-specific isoforms are conserved in insects and act as the downstream regulator in the sex determination pathway [31]. DSX controls sexual dimorphic development in insects, and mutation of sex-specific isoforms will cause male or female reproductive defects, respectively; hence, it has been targeted in development of sterile insect biotechnology [77-80]. As in Diptera, also in Lepidoptera, the $d s x$ pre-mRNA is alternatively spliced to encode transcription factors that contain a common $\mathrm{N}$-terminal 
domain and a sex-specific C-terminal domain [81]. The N-terminal domain possesses a DNA-binding motif that mediates the binding of DSX to target genes, whereas the Cterminal domain is crucial for DSX regulation of sexual development $[37,82]$. Disruptions of functions of certain isoforms of DSX lead to either sex-specific sexual-dimorphic defects or intersexual phenotypes in multiple Lepidoptera insects including B. mori, A. ipsilon, Plutella xylostella and H. cunea [38,83-85].

In Drosophila, the transcription cofactor Intersex (Ix) functions together with the femalespecific product of $d s x$, DSXF, to implement female sexual differentiation [86] (Figure 2E). However, depletion of $i x$ in the silkworm does not affect gonad development or splicing of the $d s x$ pre-mRNA in either sex, suggesting that $i x$ functions differently in silkworms than in flies [87]. The transcription factor Fruitless (Fru) plays roles in sexual behaviors and is regulated by the sex determination cascade in flies [7]. A recent study in the silkworm demonstrated that Fru is also affected by the upstream sex-determining factors and acts together with DSX to regulate both mating and courtship behavior [88].

Although DSX exists in the majority of insect species, the mechanisms by which it functions in sex determination and subsequent developmental processes are poorly understood in most insect species. Only a few genes directly controlled by DSX have been identified, although numerous targets of DSX have been predicted and analyzed on the genome-wide scale in Drosophila $[89,90]$. It remains to be determined whether the events downstream of DSX were conserved among insects during evolution [91].

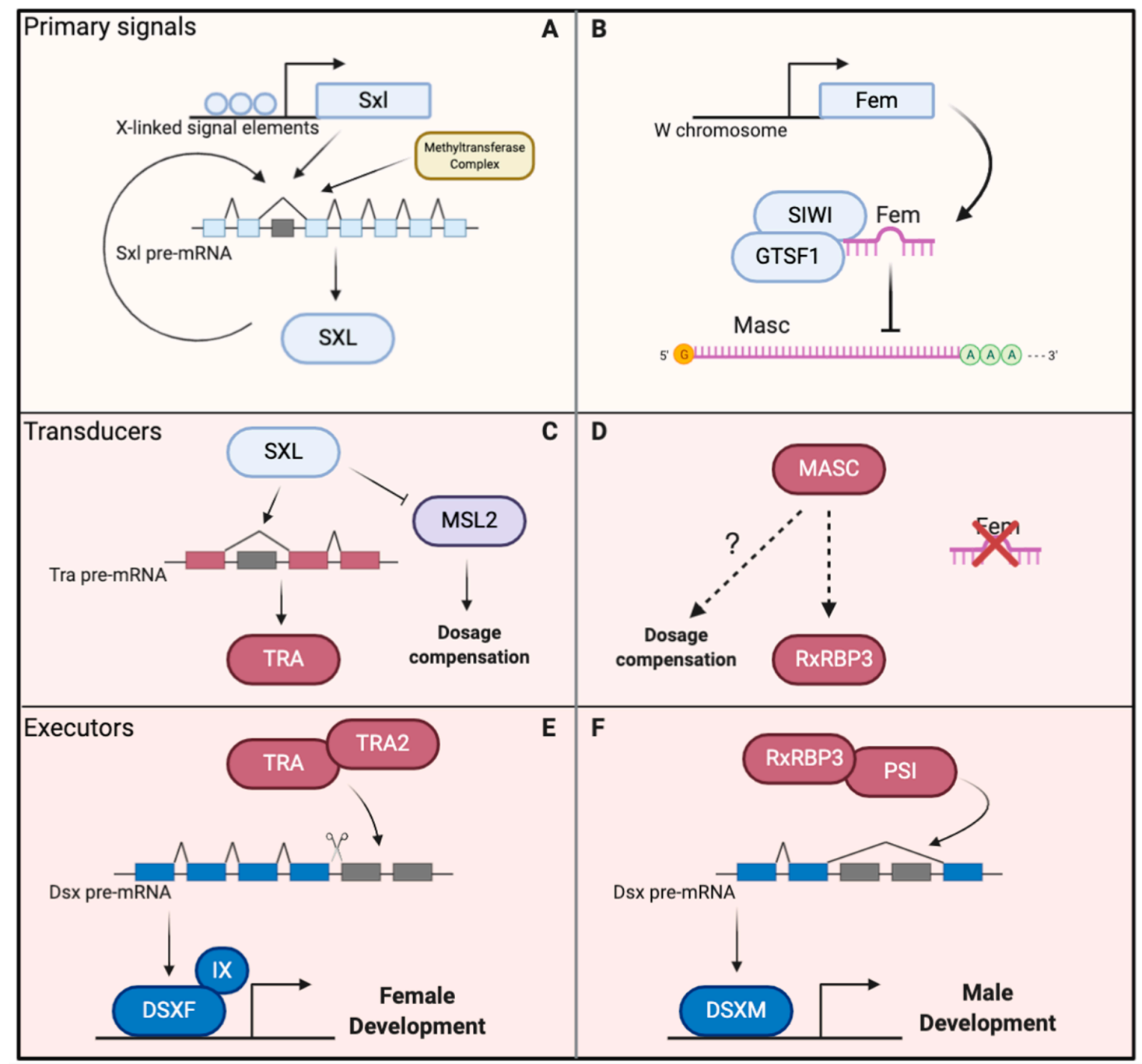

Figure 2. Comparison of the sex determination cascade between Drosophila melanogaster (A,C,E) and Bombyx mori (B,D,F). In female D. melanogaster, the dosage of several X-linked signal element proteins regulates the transcription initialization of 
Sex-lethal $(S x l)$. An autoregulatory feedback loop ensures continuous expression. Methyltransferase complex components also regulate the precise splicing of $S x l$ (A) [92-95]. The $S x l$ protein (SXL) directly binds to transformer (tra) pre-mRNA and regulates its alternative splicing. Male-specific-lethal 2 (Msl2) is inhibited at the mRNA level (C). Functional transformer protein (TRA) with transformer-2 protein (TRA2) together regulate doublesex (dsx) female-specific alternative splicing (E) [5]. The female-specific DSX (DSXF) interacts with Intersex protein (IX) to promote female development [86]. In female B. mori, the Feminizer piRNA (Fem) derived from the female W chromosome is postulated to interact with the protein Silkworm-PIWI (SIWI) and gametocyte-specific factor 1 (GTSF1) to form the piRNA-induced silencing complexes that silences Masculinizer (Masc) at the mRNA level (B) [24,25,28]. In male B. mori, the Masc protein (MASC) increases the expression of Bombyx mori dsx RNA-binding protein 3 (RxRBP3) (D). RxRBP3, together with the protein of P-element somatic inhibitor (PSI), regulates the male-specific alternative splicing of $d s x(\mathbf{F})[26,72,87,96]$. The male-specific DSX (DSXM) promotes male development $[37,38]$.

\section{Conclusions and Perspectives}

Genetic, molecular and biochemical studies demonstrate that the sex-determination system in the silkworm, a model lepidopteran insect, is very different from that in Diptera [11]. Although several factors have been characterized in the silkworm, how they are functionally correlated with each other is still unclear [24-28,33]. Moreover, no factors that specifically control sex transformation have been discovered, making the sex determination cascade in the silkworm elusive. If Fem as the primary signal is dominant in the sex determination cascade, overexpressing Fem in males may cause a male-to-female change. However, based on previous studies and our work, we postulate that there may exist an F-factor other than Fem as the primary signal. Besides, although SIWI and Gtsf1 have been shown to be piRNA-binding proteins, there is no direct in vivo evidence that these proteins bind to Fem. RNA-binding protein immunoprecipitation assays are required to verify this binding.

It will also be worth further investigating Masc-interacting components and downstream targets in future studies. For instance, comparison of the epigenetic markers involved in histone modifications in Masc mutants of both sexes may help us understand the dosage compensation mechanism in the silkworm. Moreover, in transformer-less species, the alternative splicing regulation of $d s x$ remains unclear. Since PSI exists in both sexes in the silkworm, we speculate that the masculinization function of PSI may depend on Masc [33,36]. No evidence has demonstrated that there is a physical interaction between Masc and PSI. Although components have been identified as PSI-interacting proteins, the expressing patterns among them have no sex bias $[97,98]$. Based on regulation by Masc, and direct interaction with PSI and $d s x$ pre-mRNA, it seems BxRBP3 has the potential function as the transducer [72]. Furthermore, Masc is also involved in masculinization in multiple lepidopterans, and whether a general cascade is conserved among them requires investigation $[21,34,35]$. Therefore, further research on the mechanism of Masc will likely be the key to solving this puzzle.

The Lepidoptera order includes both pest species and species of economic importance. Thus, it is important to understand the general mechanism of sex determination in lepidopterans. Here we compared the differences in key factors involved in sex determination in the Lepidoptera model insect silkworm and Drosophila, and we proposed some future research directions. However, it should be noted that the conception "primary signal-transducer-executor" of sex determination cascade may not fit in all insects. Perhaps in mosquitos, the primary signal gene, as a splicing factor, might directly regulate the alternative splicing of $d s x[12,13]$. With further application of next-generation sequencing and of genetic research tools in non-model insects, the diverse cascades in insects will be uncovered. By targeting sex determination genes, it will guide development of techniques for pest control. It will also further our understanding of how evolutionary selection in insects leads to adaptation and natural selection, which should in turn enable selection or engineering of desired traits in species of economic importance [99]. 
Author Contributions: Conceptualization, X.Y. and Y.H.; writing-original draft preparation, X.Y.; writing-review and editing, X.Y., Y.W., K.C., D.Y., Y.H.; figure preparation, X.Y.; supervision, Y.H.; funding acquisition, Y.H. All authors have read and agreed to the published version of the manuscript.

Funding: This research was supported by grants from the National Science Foundation of China (31530072 and 31830093).

Institutional Review Board Statement: Not applicable.

Data Availability Statement: No new data were created or analyzed in this study. Data sharing is not applicable to this article.

Acknowledgments: We thank Hongquan Yang and Jacqueline Wyatt for proof-reading of the manuscript and Jun $\mathrm{Xu}$ for critical comments on the manuscript. We also thank the anonymous reviewers and the editor panel for the efforts generously offered to help improving the manuscript.

Conflicts of Interest: The authors declare no conflict of interest.

\section{References}

1. Otto, S.P. The Evolutionary Enigma of Sex. Am. Nat. 2009. [CrossRef] [PubMed]

2. Bachtrog, D.; Mank, J.E.; Peichel, C.L.; Kirkpatrick, M.; Otto, S.P.; Ashman, T.L.; Hahn, M.W.; Kitano, J.; Mayrose, I.; Ming, R.; et al. Sex Determination: Why So Many Ways of Doing It? PLoS Biol. 2014, 12, e1001899. [CrossRef] [PubMed]

3. Sahara, K.; Yoshido, A.; Traut, W. Sex chromosome evolution in moths and butterflies. Chromosom. Res. 2012, 20, 83-94. [CrossRef] [PubMed]

4. Uller, T.; Pen, I.; Wapstra, E.; Beukeboom, L.W.; Komdeur, J. The evolution of sex ratios and sex-determining systems. Trends Ecol. Evol. 2007, 22, 292-297. [CrossRef]

5. Salz, H.K.; Erickson, J.W. Sex determination in Drosophila: The view from the top. Fly (Austin) 2010, 4, 60-70. [CrossRef]

6. Douglas, A. Harrison Sex Determination: Controlling the Master. Curr. Biol. 2007. [CrossRef]

7. Billeter, J.C.; Rideout, E.J.; Dornan, A.J.; Goodwin, S.F. Control of Male Sexual Behavior in Drosophila by the Sex Determination Pathway. Curr. Biol. 2006, 16, 766-776. [CrossRef] [PubMed]

8. Beye, M.; Hasselmann, M.; Fondrk, M.K.; Page, R.E.; Omholt, S.W. The gene csd is the primary signal for sexual development in the honeybee and encodes an SR-type protein. Cell 2003, 114, 419-429. [CrossRef]

9. Gempe, T.; Hasselmann, M.; Schiøtt, M.; Hause, G.; Otte, M.; Beye, M. Sex determination in honeybees: Two separate mechanisms induce and maintain the female pathway. PLoS Biol. 2009, 7. [CrossRef]

10. Shukla, J.N.; Palli, S.R. Sex determination in beetles: Production of all male progeny by Parental RNAi knockdown of transformer. Sci. Rep. 2012, 2. [CrossRef] [PubMed]

11. Sawanth, S.K.; Gopinath, G.; Sambrani, N.; Arunkumar, K.P. The autoregulatory loop: A common mechanism of regulation of key sex determining genes in insects. J. Biosci. 2016, 41, 283-294. [CrossRef] [PubMed]

12. Zou, Y.; Geuverink, E.; Beukeboom, L.W.; Verhulst, E.C.; van de Zande, L. A chimeric gene paternally instructs female sex determination in the haplodiploid wasp Nasonia. Science 2020, 370, 1115-1118. [CrossRef] [PubMed]

13. Verhulst, E.C.; Beukeboom, L.W.; van de Zande, L. Maternal control of haplodiploid sex determination in the wasp Nasonia. Science 2010, 328, 620-623. [CrossRef]

14. Hall, A.B.; Basu, S.; Jiang, X.; Qi, Y.; Timoshevskiy, V.A.; Biedler, J.K.; Sharakhova, M.V.; Elahi, R.; Anderson, M.A.E.; Chen, X.G.; et al. A male-determining factor in the mosquito Aedes aegypti. Science 2015, 348, 1268-1270. [CrossRef] [PubMed]

15. Aryan, A.; Anderson, M.A.E.; Biedler, J.K.; Qi, Y.; Overcash, J.M.; Naumenko, A.N.; Sharakhova, M.V.; Mao, C.; Adelman, Z.N.; $\mathrm{Tu}, \mathrm{Z}$. Nix alone is sufficient to convert female Aedes aegypti into fertile males and myo-sex is needed for male flight. Proc. Natl. Acad. Sci. USA 2020, 117, 17702-17709. [CrossRef]

16. Sharma, A.; Heinze, S.D.; Wu, Y.; Kohlbrenner, T.; Morilla, I.; Brunner, C.; Wimmer, E.A.; Van De Zande, L.; Robinson, M.D.; Beukeboom, L.W.; et al. Male sex in houseflies is determined by Mdmd, a paralog of the generic splice factor gene CWC22. Science 2017, 356, 642-645. [CrossRef] [PubMed]

17. Meccariello, A.; Salvemini, M.; Primo, P.; Hall, B.; Koskinioti, P.; Dalíková, M.; Gravina, A.; Gucciardino, M.A.; Forlenza, F.; Gregoriou, M.E.; et al. Maleness-on-the-Y (MoY) orchestrates male sex determination in major agricultural fruit fly pests. Science 2019, 365, 1457-1460. [CrossRef]

18. Krzywinska, E.; Dennison, N.J.; Lycett, G.J.; Krzywinski, J. A maleness gene in the malaria mosquito Anopheles gambiae. Science 2016, 353, 67-69. [CrossRef]

19. Bopp, D.; Saccone, G.; Beye, M. Sex determination in insects: Variations on a common theme. Sex. Dev. 2014, 8, 20-28. [CrossRef] [PubMed]

20. Geuverink, E.; Beukeboom, L.W. Phylogenetic distribution and evolutionary dynamics of the sex determination genes doublesex and transformer in insects. Sex. Dev. 2014, 8, 38-49. [CrossRef]

21. Wang, Y.H.; Chen, X.E.; Yang, Y.; Xu, J.; Fang, G.Q.; Niu, C.Y.; Huang, Y.P.; Zhan, S. The Masc gene product controls masculinization in the black cutworm, Agrotis ipsilon. Insect Sci. 2019, 26, 1037-1044. [CrossRef] 
22. Suzuki, M.G. Sex determination: Insights from the silkworm. J. Genet. 2010, 89, 357-363. [CrossRef]

23. Fujii, T.; Shimada, T. Sex determination in the silkworm, Bombyx mori: A female determinant on the W chromosome and the sex-determining gene cascade. Semin. Cell Dev. Biol. 2007, 18, 379-388. [CrossRef] [PubMed]

24. Kiuchi, T.; Koga, H.; Kawamoto, M.; Shoji, K.; Sakai, H.; Arai, Y.; Ishihara, G.; Kawaoka, S.; Sugano, S.; Shimada, T.; et al. A single female-specific piRNA is the primary determiner of sex in the silkworm. Nature 2014, 509, 633-636. [CrossRef]

25. Li, Z.; You, L.; Yan, D.; James, A.A.; Huang, Y.; Tan, A. Bombyx mori histone methyltransferase BmAsh2 is essential for silkworm piRNA-mediated sex determination. PLoS Genet. 2018, 14, e1007245. [CrossRef] [PubMed]

26. Sakai, H.; Sumitani, M.; Chikami, Y.; Yahata, K.; Uchino, K.; Kiuchi, T.; Katsuma, S.; Aoki, F.; Sezutsu, H.; Suzuki, M.G. Transgenic Expression of the piRNA-Resistant Masculinizer Gene Induces Female-Specific Lethality and Partial Female-to-Male Sex Reversal in the Silkworm, Bombyx mori. PLoS Genet. 2016, 12, e1006203. [CrossRef]

27. Yang, F.; Zhang, Z.; Hu, B.; Yu, Y.; Tan, A. The role of Bmznf-2 in the silkworm. Insect Sci. 2020, 1-44. [CrossRef]

28. Chen, K.; Yu, Y.; Yang, D.; Yang, X.; Tang, L.; Liu, Y.; Luo, X.; Walter, J.R.; Liu, Z.; Xu, J.; et al. Gtsf1 is essential for proper female sex determination and transposon silencing in the silkworm, Bombyx mori. PLoS Genet. 2020. [CrossRef] [PubMed]

29. Verhulst, E.C.; van de Zande, L.; Beukeboom, L.W. Insect sex determination: It all evolves around transformer. Curr. Opin. Genet. Dev. 2010, 20, 376-383. [CrossRef]

30. Sánchez, L. Sex-determining mechanisms in insects. Int. J. Dev. Biol. 2008, 52, 837-856. [CrossRef]

31. Matson, C.K.; Zarkower, D. Sex and the singular DM domain: Insights into sexual regulation, evolution and plasticity. Nat. Rev. Genet. 2012, 13, 163-174. [CrossRef]

32. Traut, W.; Sahara, K.; Marec, F. Sex chromosomes and sex determination in Lepidoptera. Sex. Dev. 2007, 1, 332-346. [CrossRef]

33. Xu, J.; Chen, S.; Zeng, B.; James, A.A.; Tan, A.; Huang, Y. Bombyx mori P-element Somatic Inhibitor (BmPSI) Is a Key Auxiliary Factor for Silkworm Male Sex Determination. PLoS Genet. 2017, 13, e1006576. [CrossRef]

34. Lee, J.; Kiuchi, T.; Kawamoto, M.; Shimada, T.; Katsuma, S. Identification and functional analysis of a Masculinizer orthologue in Trilocha varians (Lepidoptera: Bombycidae). Insect Mol. Biol. 2015, 24, 561-569. [CrossRef] [PubMed]

35. Fukui, T.; Kiuchi, T.; Shoji, K.; Kawamoto, M.; Shimada, T.; Katsuma, S. In vivo masculinizing function of the Ostrinia furnacalis Masculinizer gene. Biochem. Biophys. Res. Commun. 2018, 503, 1768-1772. [CrossRef]

36. Suzuki, M.G.; Imanishi, S.; Dohmae, N.; Nishimura, T.; Shimada, T.; Matsumoto, S. Establishment of a Novel In Vivo Sex-Specific Splicing Assay System To Identify a trans-Acting Factor That Negatively Regulates Splicing of Bombyx mori dsx Female Exons. Mol. Cell. Biol. 2008, 28, 333-343. [CrossRef]

37. Suzuki, M.G.; Funaguma, S.; Kanda, T.; Tamura, T.; Shimada, T. Role of the male BmDSX protein in the sexual differentiation of Bombyx mori. Evol. Dev. 2005, 7, 58-68. [CrossRef]

38. Xu, J.; Zhan, S.; Chen, S.; Zeng, B.; Li, Z.; James, A.A.; Tan, A.; Huang, Y. Sexually dimorphic traits in the silkworm, Bombyx mori, are regulated by doublesex. Insect Biochem. Mol. Biol. 2017, 80, 42-51. [CrossRef]

39. Hasimoto, H. The role of the W-chromosome in the sex determination of Bombyx mori. Jpn. J. Genet. 1933, 8, 245-247. [CrossRef]

40. Abe, H.; Fujii, T.; Tanaka, N.; Yokoyama, T.; Kakehashi, H.; Ajimura, M.; Mita, K.; Banno, Y.; Yasukochi, Y.; Oshiki, T.; et al. Identification of the female-determining region of the $W$ chromosome in Bombyx mori. Genetica 2008, 133, 269-282. [CrossRef]

41. Xia, Q.; Zhou, Z.; Lu, C.; Cheng, D.; Dai, F.; Li, B.; Zhao, P.; Zha, X.; Cheng, T.; Chai, C.; et al. A draft sequence for the genome of the domesticated silkworm (Bombyx mori). Science 2004, 306, 1937-1940. [CrossRef]

42. Abe, H.; Mita, K.; Yasukochi, Y.; Oshiki, T.; Shimada, T. Retrotransposable elements on the W chromosome of the silkworm, Bombyx mori. Cytogenet. Genome Res. 2005, 110, 144-151. [CrossRef] [PubMed]

43. Kawaoka, S.; Hayashi, N.; Suzuki, Y.; Abe, H.; Sugano, S.; Tomari, Y.; Shimada, T.; Katsuma, S. The Bombyx ovary-derived cell line endogenously expresses PIWI/PIWI-interacting RNA complexes. RNA 2009, 15, 1258-1264. [CrossRef] [PubMed]

44. Kawaoka, S.; Kadota, K.; Arai, Y.; Suzuki, Y.; Fujii, T.; Abe, H.; Yasukochi, Y.; Mita, K.; Sugano, S.; Shimizu, K.; et al. The silkworm W chromosome is a source of female-enriched piRNAs. Rna 2011, 17, 2144-2151. [CrossRef] [PubMed]

45. Kawaoka, S.; Mitsutake, H.; Kiuchi, T.; Kobayashi, M.; Yoshikawa, M.; Suzuki, Y.; Sugano, S.; Shimada, T.; Kobayashi, J.; Tomari, Y.; et al. A role for transcription from a piRNA cluster in de novo piRNA production. RNA 2012, 18, 265-273. [CrossRef] [PubMed]

46. Hara, K.; Fujii, T.; Suzuki, Y.; Sugano, S.; Shimada, T.; Katsuma, S.; Kawaoka, S. Altered expression of testis-specific genes, piRNAs, and transposons in the silkworm ovary masculinized by a W chromosome mutation. BMC Genom. 2012, 13. [CrossRef] [PubMed]

47. Kawaoka, S.; Arai, Y.; Kadota, K.; Suzuki, Y.; Hara, K.; Sugano, S.; Shimizu, K.; Tomari, Y.; Shimada, T.; Katsuma, S. Zygotic amplification of secondary piRNAs during silkworm embryogenesis. RNA 2011, 17, 1401-1407. [CrossRef]

48. Ishizu, H.; Siomi, H.; Siomi, M.C. Biology of Piwi-interacting RNAs: New insights into biogenesis and function inside and outside of germlines. Genes Dev. 2012, 26, 2361-2373. [CrossRef]

49. Sato, K.; Siomi, M.C. The piRNA pathway in Drosophila ovarian germ and somatic cells. Proc. Jpn. Acad. Ser. B Phys. Biol. Sci. 2020, 96, 32-42. [CrossRef]

50. Sakakibara, K.; Siomi, M.C. The PIWI-Interacting RNA Molecular Pathway: Insights from Cultured Silkworm Germline Cells. BioEssays 2018, 40. [CrossRef]

51. Czech, B.; Munafò, M.; Ciabrelli, F.; Eastwood, E.L.; Fabry, M.H.; Kneuss, E.; Hannon, G.J. PiRNA-guided genome defense: From biogenesis to silencing. Annu. Rev. Genet. 2018, 52, 131-157. [CrossRef] [PubMed] 
52. Ozata, D.M.; Gainetdinov, I.; Zoch, A.; O'Carroll, D.; Zamore, P.D. PIWI-interacting RNAs: Small RNAs with big functions. Nat. Rev. Genet. 2019, 20, 89-108. [CrossRef]

53. Ohtani, H.; Iwasaki, Y.W.; Shibuya, A.; Siomi, H.; Siomi, M.C.; Saito, K. DmGTSF1 is necessary for Piwi-piRISC-mediated transcriptional transposon silencing in the Drosophila ovary. Genes Dev. 2013, 27, 1656-1661. [CrossRef]

54. Dönertas, D.; Sienski, G.; Brennecke, J. Drosophila Gtsf1 is an essential component of the Piwi-mediated transcriptional silencing complex. Genes Dev. 2013, 27, 1693-1705. [CrossRef] [PubMed]

55. Sienski, G.; Dönertas, D.; Brennecke, J. Transcriptional silencing of transposons by Piwi and maelstrom and its impact on chromatin state and gene expression. Cell 2012, 151, 964-980. [CrossRef] [PubMed]

56. Chen, K.; Chen, S.; Xu, J.; Yu, Y.; Liu, Z.; Tan, A.; Huang, Y. Maelstrom regulates spermatogenesis of the silkworm, Bombyx mori. Insect Biochem. Mol. Biol. 2019, 109, 43-51. [CrossRef]

57. Izumi, N.; Shoji, K.; Sakaguchi, Y.; Honda, S.; Kirino, Y.; Suzuki, T.; Katsuma, S.; Tomari, Y. Identification and Functional Analysis of the Pre-piRNA 3' Trimmer in Silkworms. Cell 2016, 164, 962-973. [CrossRef] [PubMed]

58. Chen, S.; Liu, Y.; Yang, X.; Liu, Z.; Luo, X.; Xu, J.; Huang, Y. Dysfunction of dimorphic sperm impairs male fertility in the silkworm. Cell Discov. 2020, 6. [CrossRef] [PubMed]

59. Katsuma, S.; Sugano, Y.; Kiuchi, T.; Shimada, T. Two conserved cysteine residues are required for the masculinizing activity of the silkworm Masc protein. J. Biol. Chem. 2015, 290, 26114-26124. [CrossRef] [PubMed]

60. Fukui, T.; Kawamoto, M.; Shoji, K.; Kiuchi, T.; Sugano, S.; Shimada, T.; Suzuki, Y.; Katsuma, S. The Endosymbiotic Bacterium Wolbachia Selectively Kills Male Hosts by Targeting the Masculinizing Gene. PLoS Pathog. 2015, 11, e1005048. [CrossRef]

61. Zhao, Q.; Li, J.; Wen, M.Y.; Wang, H.; Wang, Y.; Wang, K.X.; Wan, Q.X.; Zha, X.F. A novel splice variant of the masculinizing gene masc with piRNA-cleavage-site defect functions in female external genital development in the silkworm, bombyx mori. Biomolecules 2019, 9, 318. [CrossRef] [PubMed]

62. Zhuo, J.C.; Zhang, H.H.; Xie, Y.C.; Li, H.J.; Hu, Q.L.; Zhang, C.X. Identification of a female determinant gene for the sexual determination of a hemipteran insect, the brown planthopper. bioRxiv 2019. [CrossRef]

63. Krzywinska, E.; Ferretti, L.; Li, J.; Li, J.-C.; Chen, C.-H.; Krzywinski, J. femaleless controls sex determination and dosage compensation pathways in females of the Anopheles mosquitoes. Curr. Biol. 2021, 1-8. [CrossRef]

64. Siebel, C.W.; Kanaar, R.; Rio, D.C. Regulation of tissue-specific P-element pre-mRNA splicing requires the RNA-binding protein PSI. Genes Dev. 1994, 8, 1713-1725. [CrossRef] [PubMed]

65. Labourier, E.; Adams, M.D.; Rio, D.C. Modulation of P-element pre-mRNA splicing by a direct interaction between PSI and U1 snRNP 70K protein. Mol. Cell 2001, 8, 363-373. [CrossRef]

66. Adams, M.D.; Tarng, R.S.; Rio, D.C. The alternative splicing factor PSI regulates P-element third intron splicing in vivo. Genes Dev. 1997, 11, 129-138. [CrossRef] [PubMed]

67. Amarasinghe, A.K.; Macdiarmid, R.; Adams, M.D.; Rio, D.C. An in vitro-selected RNA-binding site for the KH domain protein PSI acts as a splicing inhibitor element. RNA 2001, 7, 1239-1253. [CrossRef] [PubMed]

68. Chmiel, N.H.; Rio, D.C.; Doudna, J.A. Distinct contributions of KH domains to substrate binding affinity of Drosophila P-element somatic inhibitor protein. RNA 2006, 12, 283-291. [CrossRef] [PubMed]

69. Ignjatovic, T.; Yang, J.C.; Butler, J.; Neuhaus, D.; Nagai, K. Structural basis of the interaction between P-element somatic inhibitor and U1-70k essential for the alternative splicing of P-element transposase. J. Mol. Biol. 2005, 351, 52-65. [CrossRef]

70. Wang, Y.; Zhao, Q.; Wan, Q.X.; Wang, K.X.; Zha, X.F. P-element somatic inhibitor protein binding a target sequence in dsx pre-mrna conserved in Bombyx mori and Spodoptera litura. Int. J. Mol. Sci. 2019, 20, 2361. [CrossRef]

71. Gopinath, G.; Arunkumar, K.P.; Mita, K.; Nagaraju, J. Role of Bmznf-2, a Bombyx mori CCCH zinc finger gene, in masculinisation and differential splicing of Bmtra-2. Insect Biochem. Mol. Biol. 2016, 75, 32-44. [CrossRef]

72. Zheng, Z.Z.; Sun, X.; Zhang, B.; Pu, J.; Jiang, Z.Y.; Li, M.; Fan, Y.J.; Xu, Y.Z. Alternative splicing regulation of doublesex gene by RNA-binding proteins in the silkworm Bombyx mori. RNA Biol. 2019, 16, 809-820. [CrossRef]

73. Pane, A.; Salvemini, M.; Delli Bovi, P.; Polito, C.; Saccone, G. The transformer gene in Ceratitis capitata provides a genetic basis for selecting and remembering the sexual fate. Development 2002, 129, 3715-3725.

74. Concha, C.; Scott, M.J. Sexual development in Lucilia cuprina (Diptera, Calliphoridae) is controlled by the transformer gene. Genetics 2009, 182, 785-798. [CrossRef]

75. Liu, G.; Wu, Q.; Li, J.; Zhang, G.; Wan, F. RNAi-mediated knock-down of transformer and transformer 2 to generate male-only progeny in the oriental fruit fly, Bactrocera dorsalis (Hendel). PLoS ONE 2015, 10, e0128892. [CrossRef]

76. Li, F.; Vensko, S.P.; Belikoff, E.J.; Scott, M.J. Conservation and Sex-Specific Splicing of the transformer Gene in the Calliphorids Cochliomyia hominivorax, Cochliomyia macellaria and Lucilia sericata. PLoS ONE 2013, 8, e56303. [CrossRef] [PubMed]

77. Kyrou, K.; Hammond, A.M.; Galizi, R.; Kranjc, N.; Burt, A.; Beaghton, A.K.; Nolan, T.; Crisanti, A. A CRISPR-Cas9 gene drive targeting doublesex causes complete population suppression in caged Anopheles gambiae mosquitoes. Nat. Biotechnol. 2018, 36, 1062-1071. [CrossRef] [PubMed]

78. Simoni, A.; Hammond, A.M.; Beaghton, A.K.; Galizi, R.; Taxiarchi, C.; Kyrou, K.; Meacci, D.; Gribble, M.; Morselli, G.; Burt, A.; et al. A male-biased sex-distorter gene drive for the human malaria vector Anopheles gambiae. Nat. Biotechnol. 2020, 38, 1054-1060. [CrossRef] [PubMed]

79. Tan, A.; Fu, G.; Jin, L.; Guo, Q.; Li, Z.; Niu, B.; Meng, Z.; Morrison, N.I.; Alphey, L.; Huang, Y. Transgene-based, female-specific lethality system for genetic sexing of the silkworm, Bombyx mori. Proc. Natl. Acad. Sci. USA 2013, 110, 6766-6770. [CrossRef] 
80. Xu, J.; Wang, Y.; Li, Z.; Ling, L.; Zeng, B.; James, A.A.; Tan, A.; Huang, Y. Transcription activator-like effector nuclease (TALEN)mediated female-specific sterility in the silkworm, Bombyx mori. Insect Mol. Biol. 2014, 23, 800-807. [CrossRef]

81. Suzuki, M.G.; Ohbayashi, F.; Mita, K.; Shimada, T. The mechanism of sex-specific splicing at the doublesex gene is different between Drosophila melanogaster and Bombyx mori. Insect Biochem. Mol. Biol. 2001, 31, 1201-1211. [CrossRef]

82. Suzuki, M.G.; Funaguma, S.; Kanda, T.; Tamura, T.; Shimada, T. Analysis of the biological functions of a doublesex homologue in Bombyx mori. Dev. Genes Evol. 2003, 213, 345-354. [CrossRef]

83. Chen, X.; Cao, Y.; Zhan, S.; Tan, A.; Palli, S.R.; Huang, Y. Disruption of sex-specific doublesex exons results in male- and female-specific defects in the black cutworm, Agrotis ipsilon. Pest Manag. Sci. 2019, 75, 1697-1706. [CrossRef] [PubMed]

84. Li, X.; Liu, Q.; Liu, H.; Bi, H.; Wang, Y.; Chen, X.; Wu, N.; Xu, J.; Zhang, Z.; Huang, Y.; et al. Mutation of doublesex in Hyphantria cunea results in sex-specific sterility. Pest Manag. Sci. 2020, 76, 1673-1682. [CrossRef]

85. Wang, Y.; Chen, X.; Liu, Z.; Xu, J.; Li, X.; Bi, H.; Andongma, A.A.; Niu, C.; Huang, Y. Mutation of doublesex induces sex-specific sterility of the diamondback moth Plutella xylostella. Insect Biochem. Mol. Biol. 2019, 112, 103180. [CrossRef]

86. Garrett-Engele, C.M.; Siegal, M.L.; Manoli, D.S.; Williams, B.C.; Li, H.; Baker, B.S. intersex, a gene required for female sexual development in Drosophila, is expressed in both sexes and functions together with doublesex to regulate terminal differentiation. Development 2002, 129, 4661-4675.

87. Xu, J.; Yu, Y.; Chen, K.; Huang, Y. Intersex regulates female external genital and imaginal disc development in the silkworm. Insect Biochem. Mol. Biol. 2019, 108, 1-8. [CrossRef] [PubMed]

88. Xu, J.; Liu, W.; Yang, D.; Chen, S.; Chen, K.; Liu, Z.; Yang, X.; Meng, J.; Zhu, G.; Dong, S.; et al. Regulation of olfactory-based sex behaviors in the silkworm by genes in the sexdetermination cascade. PLoS Genet. 2020, 16, e1008622. [CrossRef]

89. Luo, S.D.; Shi, G.W.; Baker, B.S. Direct targets of the D. melanogaster DSXF protein and the evolution of sexual development. Development 2011, 138, 2761-2771. [CrossRef]

90. Clough, E.; Jimenez, E.; Kim, Y.A.; Whitworth, C.; Neville, M.C.; Hempel, L.U.; Pavlou, H.J.; Chen, Z.X.; Sturgill, D.; Dale, R.K.; et al. Sex- and tissue-specific functions of drosophila doublesex transcription factor target genes. Dev. Cell 2014, 31, 761-773. [CrossRef]

91. Baral, S.; Arumugam, G.; Deshmukh, R.; Kunte, K. Genetic architecture and sex-specific selection govern modular, male-biased evolution of doublesex. Sci. Adv. 2019, 5, 1-9. [CrossRef]

92. Guo, J.; Tang, H.W.; Li, J.; Perrimon, N.; Yan, D. Xio is a component of the Drosophila sex determination pathway and RNA N6-methyladenosine methyltransferase complex. Proc. Natl. Acad. Sci. USA 2018, 115, 3674-3679. [CrossRef] [PubMed]

93. Lence, T.; Akhtar, J.; Bayer, M.; Schmid, K.; Spindler, L.; Ho, C.H.; Kreim, N.; Andrade-Navarro, M.A.; Poeck, B.; Helm, M.; et al. M6A modulates neuronal functions and sex determination in Drosophila. Nature 2016, 540, 242-247. [CrossRef] [PubMed]

94. Kan, L.; Grozhik, A.V.; Vedanayagam, J.; Patil, D.P.; Pang, N.; Lim, K.S.; Huang, Y.C.; Joseph, B.; Lin, C.J.; Despic, V.; et al. The $\mathrm{m}^{6} \mathrm{~A}$ pathway facilitates sex determination in Drosophila. Nat. Commun. 2017, 8, 1-16. [CrossRef]

95. Haussmann, I.U.; Bodi, Z.; Sanchez-Moran, E.; Mongan, N.P.; Archer, N.; Fray, R.G.; Soller, M. M6 A potentiates Sxl alternative pre-mRNA splicing for robust Drosophila sex determination. Nature 2016, 540, 301-304. [CrossRef] [PubMed]

96. Yuzawa, T.; Matsuoka, M.; Sumitani, M.; Aoki, F.; Sezutsu, H.; Suzuki, M.G. Transgenic and knockout analyses of Masculinizer and doublesex illuminated the unique functions of doublesex in germ cell sexual development of the silkworm, Bombyx mori. BMC Dev. Biol. 2020, 20, 1-15. [CrossRef]

97. Xu, X.; Wang, K.; Zha, X. An antisense lncRNA functions in alternative splicing of Bmdsx in the silkworm, Bombyx mori. Biochem. Biophys. Res. Commun. 2019, 516, 639-644. [CrossRef] [PubMed]

98. Wang, Y.; Li, J.; Wan, Q.X.; Zhao, Q.; Wang, K.X.; Zha, X.F. Spliceosomal protein gene BmSPX regulates reproductive organ development in bombyx mori. Int. J. Mol. Sci. 2020, 21, 2579. [CrossRef]

99. Geffroy, B.; Douhard, M. The Adaptive Sex in Stressful Environments. Trends Ecol. Evol. 2019, 34, 628-640. [CrossRef] 